\title{
COMPARATIVE CYTOTOXICITY EVALUATION OF MEDICINES USED FOR PULP THERAPY OF PRIMARY TEETH
}

\author{
Rossitza Kabaktchieva ${ }^{1}$, Denitsa Momekova ${ }^{2}$, Georgi Momekov ${ }^{3}$, Natalia Gateva ${ }^{1}$ \\ 1) Department of Pediatric Dentistry, Faculty of Dental Medicine, \\ 2) Department of Pharmaceutical Technology and Biopharmaceutics, Faculty of \\ Pharmacy, \\ 3) Laboratory of Experimental Chemotherapy, Department of Pharmacology, \\ Pharmacotherapy and Toxicology, Faculty of Pharmacy, \\ Medical University - Sofia, Bulgaria
}

\section{SUMMARY:}

Introduction:Despite the eight decades of widespread clinical use of formocresol growing evidence from both experimental and clinical studies clearly indicates that formaldehyde is leaking out during pulpotomy and may participate in the development of non-target tissue damage of local and systemic character. Special attention has been paid to pulp-capping materials and especially mineral trioxide aggregate (MTA) as probable alternative of formocresol in vital pulpotomy in primary teeth, in line with its excellent biocompatibility and pro-dentinogenic properties. The overwhelming evidence that MTA is superior in terms of biological compatibilityand clinical success as compared to formocresol has conditioned the dramatic shift to MTA in routine pulpotomies.

Objective: The aim of this study was to assess the biocompatibility of resorcinol/formalin (RF) pulpotomy preparation in comparison to mineral trioxide aggregate (MTA) and calcium hydroxide cement (CHC).

Methods: Cell survival was assessed by the MTTassay (after 48, 72 or $144 \mathrm{~h}$ ) in five cell lines, namely: HDMY-Z, HEK-293, SH-SY-5Y, Neuro-2A, SaOS-2. In addition treatment-induced morphological perturbations and induction of necrosis and apoptosis were assessed in HEK-293.

Results: RF evoked strong, concentration-dependent cytotoxicity, which was evident even at significant dilution of the parent solution. In general the cytotoxicity of RF was not greatly influenced by the exposure period, especially at the higher concentrations under evaluation. In contrast the MTA extracts proved to be generally devoid of cytotoxic effects. MTA treatment actually increased the viability of SaOS-2 osteosarcoma cells, which could be attributed to the presence of calcium ions in the MTA-eluate which in turn stimulates the proliferation of this cell line.The $\mathrm{CH}$ cement extracts showed marginal cytotoxicity which was far less pronounced than that of RF and slightly superior compared to MTA.
Conclusions: In contrast to RF that exerted prominent cytotoxicity, MTA and $\mathrm{CHC}$ were biocompatible, with no evidence for decreased mitochondrial dehydrogenase activity, morphological changes in monolayer integrity or induction of apoptosis and/or necrosis. This contribution is the first systematic in vitro evaluation of the cytotoxicity of resorcinolformalin $v s$. viable pulpotomy agents. It gives further evidence for the safety advantages of viable pulp therapy products $\mathrm{CHC}$ and especially MTA as compared to the RF preparation, routinely used in Bulgaria for decades.

Key words: pulpotomy, formaldehyde, resorcinol, MTA, biocompatibility, calcium hydroxide, cytotoxicity, MTT-assay, apoptosis, necrosis.

\section{INTRODUCTION}

Worldwide, formaldehyde-based products continue to be used routinely in dentistry (1). Most dental schools in Europe, North America and elsewhere still widely advocate the dominant clinical use of formocresol (a $m$-cresol/ formaldehyde based product) pulpotomies in both carious primary and permanent teeth (2-4). In Eastern Europe, and Bulgaria in particular, primary teeth pulpotomies are performed employing a chemically analogous and therapeutically equivalent protocol based on a saturated resorcinol solution in formalin (RF), instead for formocresol (5-8).

Despite the eight decades of widespread clinical use of formocresol growing evidence from both experimental and clinical studies clearly indicates that formaldehyde is leaking out during pulpotomy and may participate in the development of non-target tissue damage of local and systemic character $(1,9,10)$. This has been argued by some authorities who consider formocresol to be devoid of significant toxicity in humans when applied in low doses (i.e. in pulpotomies) (1, 11, 12). Regardless, the immunologic and systemic distribution of ${ }^{14} \mathrm{C}$ labeled formaldehyde has been well documented $(13,14)$ and the toxic effects of formocresol and 
other formaldehyde containing agents have been clearly demonstrated in vivo and in vitro $(9,10,15-23)$. Recent clinical data evidently reinforce these observations $(2,4,10$, 13, 24).

The evidence obtained shows that formocresol even in reduced concentrations has the potential to result in negative immunologic, systemic, toxicological, and overt clinical consequences. More specifically formaldehyde employed during pulpotomy could evoke inflammation of surrounding non-target tissue and exert cytotoxic $(16,17$, $21,23)$, genotoxic and mutagenic effects $(9,19)$ leading to tissue damage ranging from vascular insult and inflammation $(3,4,25)$ to necrotic $(26,27)$ and osteolytic changes $(13)$. It is also capable of damaging the enamel and the succedaneum teeth (17). Moreover the pulpal proteins that have been treated by the formocresol or formalin/resorcinol are rendered by the host as an altered entity, recognized as potentially antigenic and immunologically foreign. Thus in addition to the local, non-specific inflammatory events evoked by formocresol the host's immune system could be sensitized to the treatment-modified materials. These could be in turn phagocytized by macrophages, enzymatically processed by neutrophils and stimulate the generation of $\mathrm{B}$ and T-cell immune response (13). This is further complicated by the overlying immunologic response to the bacteria and its by-products from the carious lesion that the treatment is supposed to remove and by non-specific stimulation of innate immunity mechanisms and cytokine production (13, $25,28)$. Besides, the genotoxic, carcinogenic and mutagenic potential of formaldehyde has been so extensively appreciated to be regarded as proven $(9,13,19,20,22,29)$. The International Agency for Research on Cancer classified formaldehyde as definitely carcinogenic for humans in June 2004 , leaving the profession to look for alternative regimens (30). On the basis of the information available, an expert working group has concluded that there is now sufficient evidence that formaldehyde causes nasopharyngeal cancer in humans, a rare cancer in developed countries, limited evidence for cancer of the nasal cavity and paranasal sinuses, and "strong but not sufficient evidence" for leukemia $(4,30)$. Therefore, biologic manifestations of a simple formocresol pulpotomy could well extend beyond the transient local events and can be significant and potentially systemically harmful to a patient $(2-4,24)$.

Apparently the above stated evidence-based dentistry has provided overwhelming scientific and clinical data to support the removal of formocresol from human use especially in the pediatric population $(10,13)$. Thus during the last several years the clinical role of formocresol has been subject to significant clinical debate and reevaluation $(1,10)$. It has been shown that many clinical studies supporting the use of formocresol have been based on old, imprecise, short-term data $(2-4,10,24)$. On these grounds many clinicians in Western Europe and North America tend to be increasingly reluctant regarding the usefulness of formocresol. Thus in a survey in Great Britain it has been shown that $54 \%$ of the pediatric dentists stated they were concerned about the safety profile of formocresol. Conversely, in an USA study $37 \%$ of endodontists and $18 \%$ of the pediatric dentists were concerned about the carcinogenicity of formocresol (13).

As a result of this compelling evidence, there has been a rigorous and diligent effort to design and elaborate alternative materials and procedures for use in pulpotomies $(4,31-33)$. Ideally such agents would guarantee the radicular pulp preservation in primary teeth until the time of their physiological exfoliation, while at the same time avoiding the side effects and long term toxicities from formaldehydecontaining medicaments. The most important medicaments and procedures studied in primary teeth pulpotomy include electrosurgery, laser, glutaraldehyde, ferric sulphate, freezedried bone, bone morphogenic protein and osteogenic protein, among others $(2-4,15,24)$. Recently, advances in biomedical research opened avenues for the design of new methods of dental treatment, aiming at regeneration of the dentin-pulp complex. Such approaches have been based on the understanding of the molecular and cellular mechanisms regulating the dentinogenesis processes during dental tissue repair and their potential for clinical exploitation $(2,4,10$, 31). Accordingly, the research focus has been re-targeted from preservation and conservation to regeneration of the remaining pulp tissue $(3,4,31,32,34-36)$. In this context special attention has been paid to pulp-capping materials and especially mineral trioxide aggregate (MTA) as probable alternative of formocresol in vital pulpotomy in primary teeth, in line with its excellent biocompatibility and prodentinogenic properties $(32,34,37-49)$. The overwhelming evidence that MTA is superior in terms of biological compatibility $(18,28,39,41,47,50-53)$ and clinical success as compared to formocresol $(2,3,24,33-36,45,53-64)$ has conditioned the dramatic shift to MTA in routine pulpotomies (2-4, 31-36, 55, 61). Nevertheless, one must continue to ascertain the in vitro properties, long-term efficacy, biological and clinical use of MTA. Moreover there are alternative capping agents (e.g. Portland cement, calcium hydroxide and calcium silicate based cements etc.), which could be regarded as possible cheaper alternatives for MTA $(4,45,58)$, requiring for further experimental and clinical research and evaluation. Despite the cytotoxicity of formocresol has been subject to numerous investigations the in vitro biosafety and compatibility profile of resorcinol/formalin being the dominant pulpotomy preparation in Eastern Europe is generally unexplored. On these grounds this study is aimed at thorough comparative evaluation of biocompatibility profiles of the three regimens most often employed in primary teeth pulpotomy in Bulgaria, namely resorcinol/formalin solution for mortal pulp management, or calcium hydroxide and MTA cements for vital pulp treatment. 


\section{MATERIALS AND METHODS}

Pulpotomy agents and solutions. Formulations of the different agents were prepared in the laboratory according to the composition of the different materials as used clinically. The used chemicals were of reagent-grade quality, obtained from licensed dental material supply companies.

The RF solution was prepared according to the Bulgarian clinical protocol, as a saturated solution of resorcinol into $40 \%$ aqueous formaldehyde $(5,6)$. It was then diluted 1:1 with PBS to yield formaldehyde concentration of ca. $20 \%$, thus mimicking the $\mathrm{HCHO}$ content in the most widely used Buckley's formulation of formocresol. Thereafter, for the bioassays the cells were exposed to serial dilutions of the RF solution, namely $1: 25$, 1:100, 1:200 and 1: 1,000 in PBS. The selected concentrations were either higher or lower as compared to the clinically relevant level of exposure of non-target tissues, corresponding to 1:100 formocresol (Buckley's formulation) $(26,65)$.

Two vital pulpotomy capping agents namely mineral trioxide aggregate (MTA; white, Angelus Soluzxes Odontolygicas, Londrina, PR, Brazil) and $\mathrm{Ca}(\mathrm{OH})_{2}(\mathrm{CHC}$; Dycal ${ }^{\circledR}$-Dentsplay) were used. They were prepared according to the manufacturer's instructions and after mixing, the cements were stored in an incubator at $100 \%$ relative humidity and $37^{\circ} \mathrm{C}$ for 1 day of hydration. The cements were then sterilized in ultraviolet light for 1 hour and stored in serum-free RPMI-1640 medium in a polypropylene tube for 3 days. The concentrations of the cement elution solutions were adjusted to $1,10,30$, and $100 \mathrm{mg} / \mathrm{mL}$.

Cell lines and culture conditions. In this study the following cell lines were used:, HD-MY-Z (Hodgkin lymphoma, human), HEK-293 (human embryonal kidney epithelium), SAOS-2 (human osteogenic sarcoma), SH-SY$5 \mathrm{Y}$ (human neuroblastoma) and Neuro2A (murine neuroblastoma). Except for HEK-293 and SH-SY-5Y, which originated from American Type Cell Culture (ATCC), all cell lines were obtained from the German Collection of Microorganisms and Cell Cultures (DSMZ GmbH, Braunschweig, Germany). The cells were grown in controlled environment - cell culture flasks at $37^{\circ} \mathrm{C}$ in an incubator 'BB 16-Function Line' Heraeus (Kendro, Hanau, Germany) with humidified atmosphere and $5 \% \mathrm{CO}_{2}$. HDMY-Z were cultured as semi-adherent, and the other cell lines as monolayer cultures. SAOS-2 cells were grown in $85 \%$ McCoy's 5A supplemented with $15 \%$ fetal bovine serum (FBS), whereas for the other cells the growth medium was RPMI-1640 supplemented with 10\% (FBS) and $2 \mathrm{mM}$ L-glutamine. The cell lines were reset by trypsinization two times per week.

MTT-dye reduction assay. Cell survival was assessed by the MTT-dye reduction assay, which is based on the ability of mitochondrial succinate dehydrogenases in viable cells to reduce a yellow tetrazolium salt to violet formazan product which is detected spectrophotometrically. The procedure was carried out as previously described (66). Exponentially growing cells were plated in 96-well sterile plates at a density of $10^{4}$ cells/well in $100 \mathrm{~mL}$ of medium and were incubated for $24 \mathrm{~h}$. Thereafter the cells were exposed to serial dilutions of the resorcinol/formalin solution or the cement extracts for 48,72 or $144 \mathrm{~h}$. For each concentration a set of 8 wells was used. After the exposure period $10 \mathrm{~mL}$ aliquots from a $5 \mathrm{mg} / \mathrm{ml}$ MTT solution were added to each well and the plates were further incubated for $4 \mathrm{~h}$ at $37^{\circ} \mathrm{C}$ in a humidified $5 \% \mathrm{CO}_{2}$ atmosphere. The formazan crystals were solubilized by addition of $\mathrm{HCOOH}$ (5\%) acidified 2-propanol. The MTT-formazan absorbance was read on a microprocessor controlled micro-plate reader (Labexim LMR-1). Results were normalized as percentage of the untreated control (set as 100\% viability).

Apoptosis/necrosis assay. The DNA fragmentation as a quantitative merit of the ability of tested compounds to induce cell death was detected using a commercially available 'Cell Death Detection ELISA ${ }^{\text {PLUS' }}$ ' Applied Science), after 12 or $24 \mathrm{~h}$ treatment of HEK-293 cells, according to the manufacturer's instructions. The levels of DNA-fragments in the cytosolic fraction of treated cells (apoptotic fragmentation) and those in the culture supernatants (necrotic) were presented as enrichment factors (EF). These were calculated by dividing the $405 \mathrm{~nm}$ absorption of treated samples by the corresponding absorption of the untreated control. Each test was run in triplicate.

Morphological assay. The $48 \mathrm{~h}$ MTT-assay treatment protocol was mimicked in established confluent HEK-293 cell monolayers (cultured in sterile Petri dishes) in order to register defects in the monolayer integrity and cellular density, undetectable by the MTT-dye reduction assay. The exposed cultures where examined by a phase-contrast light microscope and photographed with a digital camera $48 \mathrm{~h}$ post treatment. The results were interpreted using the grade scale, described in USP 28 (2005) (grades 0-4) for assessment of the cytotoxic potential of tested materials, as follows: grade 0 - none reactivity (discrete intracytoplasmic granules, no cell lysis); grade 1 - slight reactivity (Not more than $20 \%$ of the cells are round, loosely attached and without intracytoplasmic granules; occasional lysed cells are present); grade 2 - mild reactivity (not more than $50 \%$ of the cells are round and devoid of intracytoplasmic granules, no extensive cell lysis and empty areas between cells); grade 3 - moderate (Not more than $70 \%$ of cell layers contain rounded cells or are lysed); grade 4 -severe (nearly complete destruction of the cell layers).

Data processing and statistics. The cytotoxicity MTTassay was carried out in eight separate experiments, whereas the morphological, apoptosis/necrosis assays were run in triplicate. Statistical processing exploited Student's t-test with $p d \leq 0.05$ set as significance level. 


\section{RESULTS}

The cytotoxicity of the agents was assessed by the MTT-dye reduction assay in a panel of cell lines, representative for cellular populations that would have been exposed to the chemical entities in pulpotomy medications within a clinical situation, namely: HD-MY-Z (histiocytes/ fibroblasts), HEK-293 (epithelium), SH-SY-5Y and Neuro$2 \mathrm{~A}$ (neurons) and SaOS-2 (calcified tissue). The cell survival after exposure to resorcinol/formalin (RF) solutions, or eluate extracts from MTA or $\mathrm{Ca}(\mathrm{OH})_{2}$ cement $(\mathrm{CHC})$ is presented in figures 1,2 and 3 respectively.

RF evoked strong, concentration-dependent cytotoxicity, which was evident even at significant dilution of the parent solution (Fig. 1). At the highest concentration tested (1:25 dilution) the cellular viability was greatly decreased in all cell lines. In general the cytotoxicity of RF was not greatly influenced by the exposure period, especially at the higher concentrations under evaluation.

In contrast the MTA extracts proved to be generally devoid of cytotoxic effects. Only slight decreases in cellular viability were encountered at the highest concentration tested after $48 \mathrm{~h}$ exposure in HEK-293, SaOS-2, and Neuro-2A cells (Fig. 2). The same treatment intensity however, after longer exposure was associated with less pronounced decrease in cell viability. Noteworthy MTA treatment actually increased the viability of SaOS-2 osteosarcoma cells, which could be attributed to the presence of calcium ions in the MTA-eluate which in turn stimulates the proliferation of this cell line.

The CHC extracts showed marginal cytotoxicity which was far less pronounced than that of RF and slightly superior compared to MTA (Fig. 3). This could be due to release of hydroxide ions during the extraction process and $\mathrm{pH}$-modulation in the culture environment. Noteworthy, the effects of $\mathrm{CHC}$ were evident after $48 \mathrm{~h}$ exposure, but invariably at longer exposure periods the cell survival fractions tended to increase to values non-significantly different from control group.
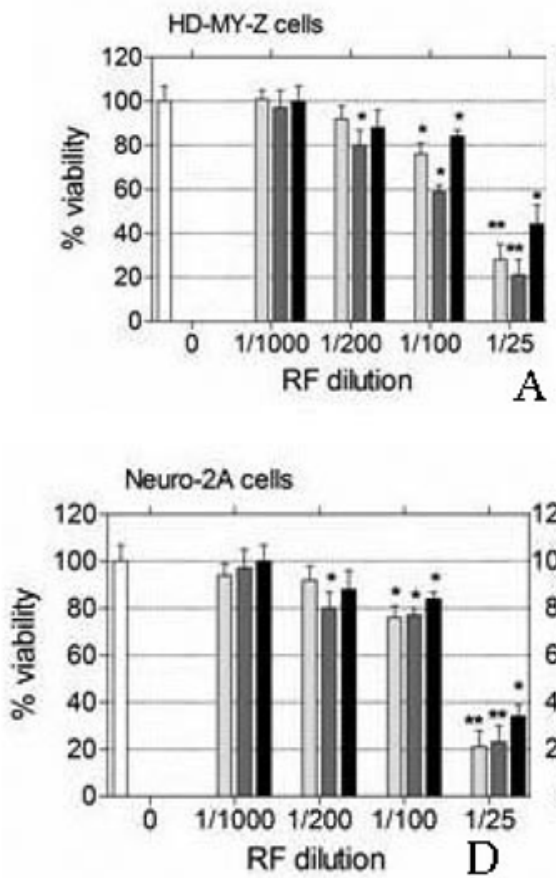

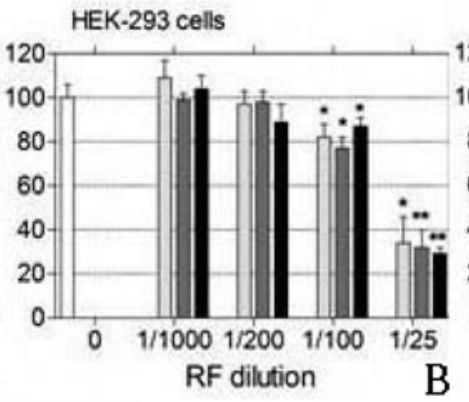

SaOS- 2 cells

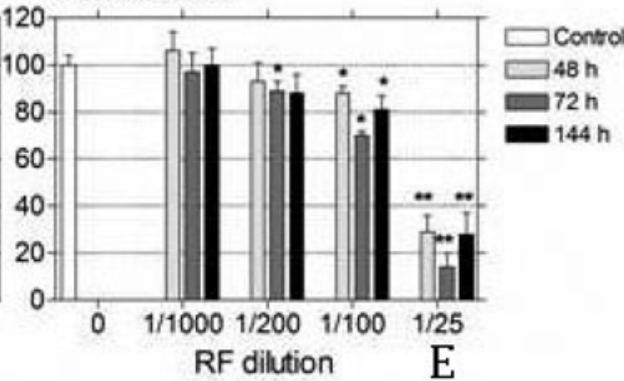

Cellular viability following resorcinol/ formalin (RF) continuous exposure for 48,72 or $144 \mathrm{~h}$, as assessed by the MTT-dye reduction assay. Each column represents the arithmetic mean + sd of 8 separate experiments. Asterisks indicate statistically significant differences as compared to the untreated control $(* \mathrm{p}<0,05$; $* \mathrm{p}<0,01)$

Fig. 1 A, B, C, D, E. Cytotoxicity of resorcinol/formalin (RF) in a panel of cell lines after continuous exposure as assessed by the MTT-dye reduction assay. 

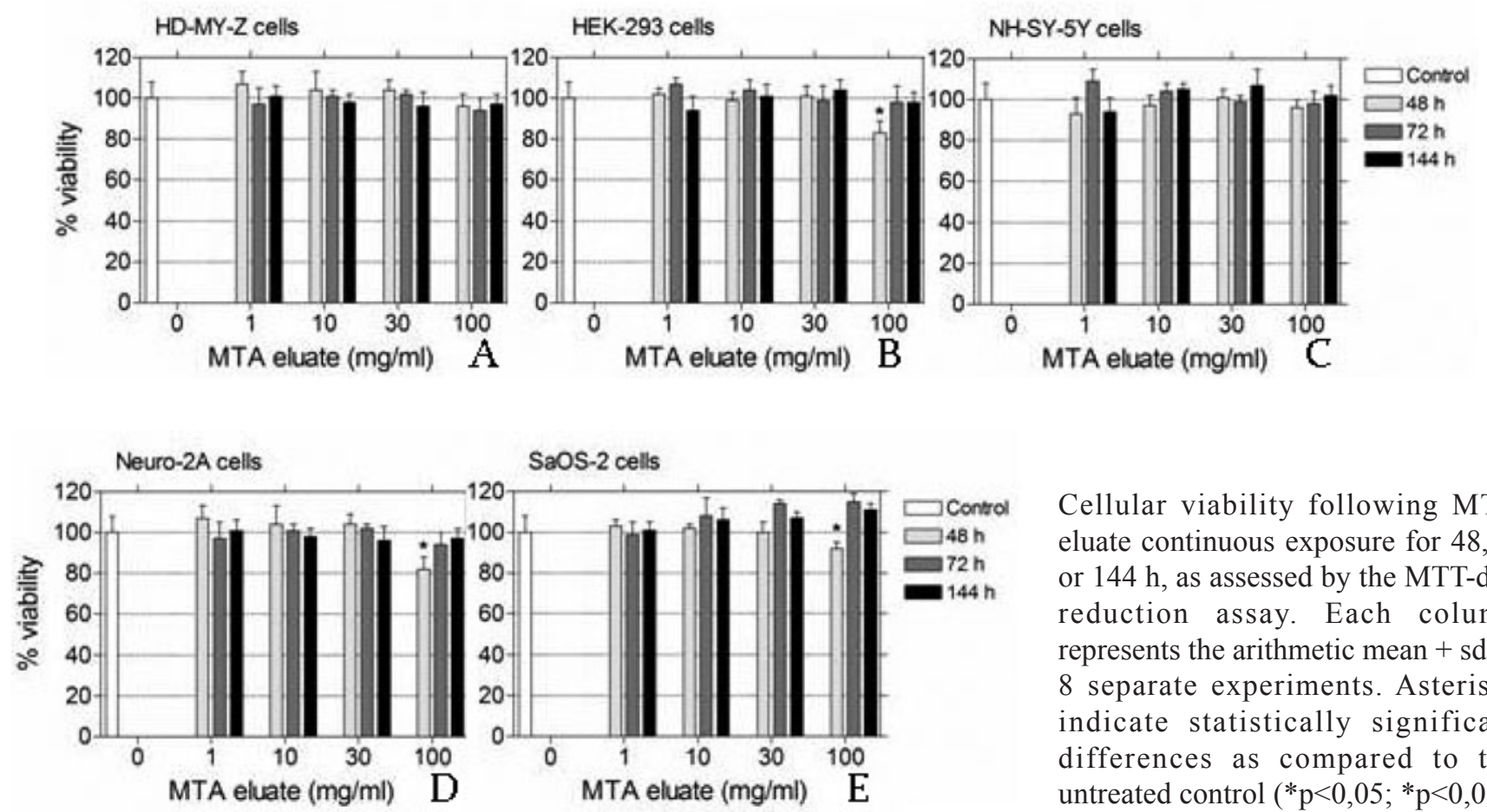

Cellular viability following MTA eluate continuous exposure for 48,72 or $144 \mathrm{~h}$, as assessed by the MTT-dye reduction assay. Each column represents the arithmetic mean $+\mathrm{sd}$ of 8 separate experiments. Asterisks indicate statistically significant differences as compared to the untreated control $\left({ }^{*} \mathrm{p}<0,05 ;{ }^{*} \mathrm{p}<0,01\right)$

Fig. 2 A, B, C, D, E. Cytotoxicity of MTA extracts in a panel of cell lines after continuous exposure as assessed by the MTT-dye reduction assay.
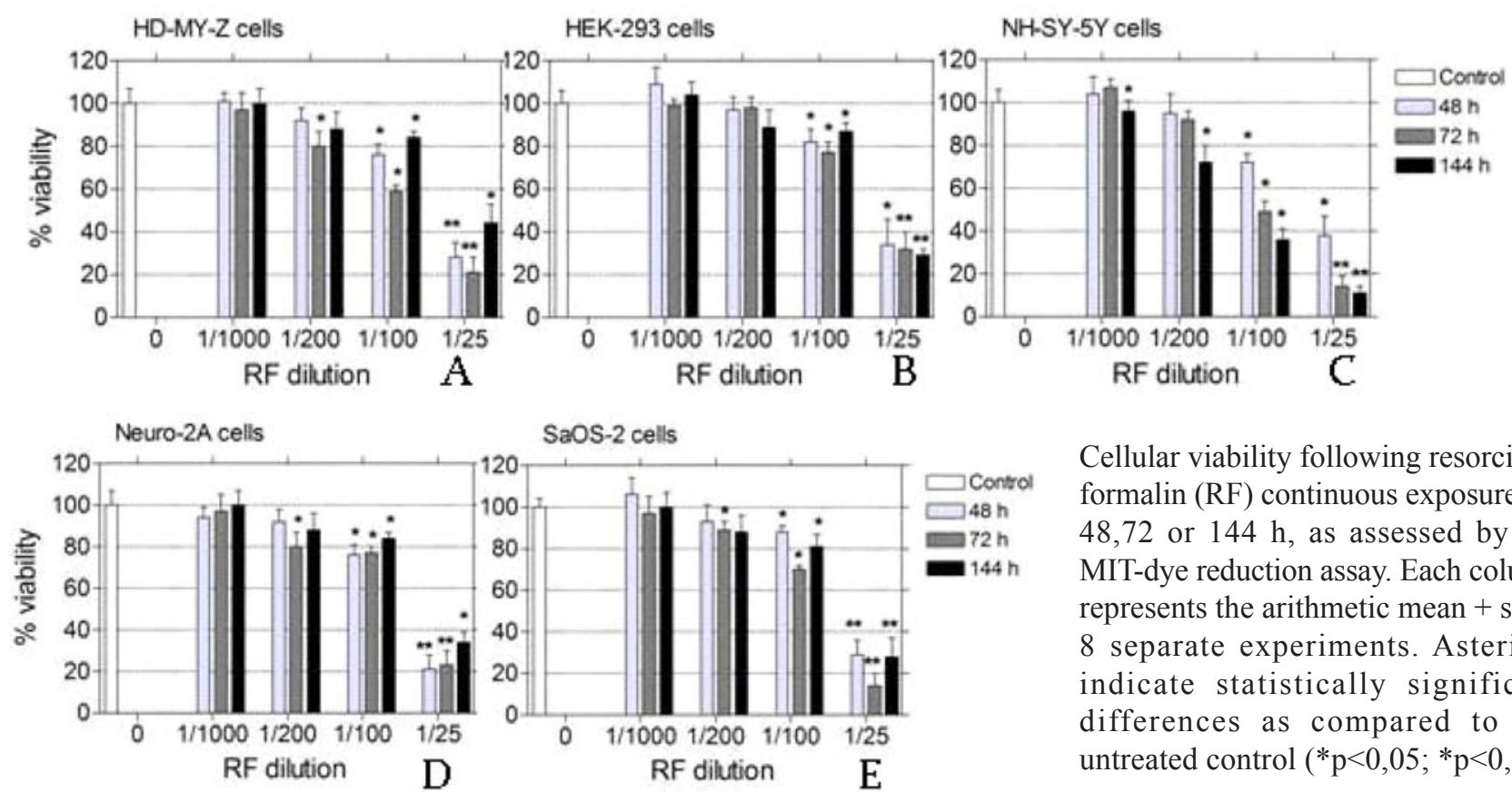

Cellular viability following resorcinol/ formalin (RF) continuous exposure for 48,72 or $144 \mathrm{~h}$, as assessed by the MIT-dye reduction assay. Each column represents the arithmetic mean + sd of 8 separate experiments. Asterisks indicate statistically significant differences as compared to the untreated control $\left({ }^{*} p<0,05 ;{ }^{*} p<0,01\right)$

Fig. 3 A, B, C, D, E. Cytotoxicity of calcium hydroxide cement extracts in a panel of cell lines after continuous exposure as assessed by the MTT-dye reduction assay. 
The MTT-data where corroborated by a morphological evaluation of established HEK-293 monolayers after $48 \mathrm{~h}$ treatment. Evident from the results summarized in Table 1 and Fig. 4 MTA or CHC extracts failed to induce any detectable changes relative to the control group, throughout the evaluated concentration range, while cytotoxic RF proved to greatly affect the monolayer integrity, lower the cell density, and at the highest concentration applied evoked prominent signs of cytotoxicity (rounded cells, detached cells and signs for disruption of membrane integrity).

Table 1. Morphological assessment of the cytotoxic effects of the tested pulpotomy agents against established HEK293 monolayers after $48 \mathrm{~h}$ exposure.

\begin{tabular}{|c|c|c|c|}
\hline Treatment series & \multicolumn{3}{|c|}{ Cytotoxicity grades $^{1}$} \\
\hline \multirow[t]{2}{*}{ Resorcinol/formalin } & $1: 25$ & $1: 100$ & $1: 200$ \\
\hline & Grade 4 & Grade 3 & Grade 1 \\
\hline \multirow[t]{2}{*}{ Mineral trioxide aggregate } & $100 \mathrm{mg} / \mathrm{ml}$ & $30 \mathrm{mg} / \mathrm{ml}$ & $10 \mathrm{mg} / \mathrm{ml}$ \\
\hline & Grade 0 & Grade 0 & Grade 0 \\
\hline \multirow[t]{2}{*}{ Calcium hydroxyde cement } & $100 \mathrm{mg} / \mathrm{ml}$ & $30 \mathrm{mg} / \mathrm{ml}$ & $10 \mathrm{mg} / \mathrm{ml}$ \\
\hline & Grade 0 & Grade 0 & Grade 0 \\
\hline
\end{tabular}

${ }^{1}$ According to USP28: Grade 0 - None reactivity; Grade 1 slight reactivity; Grade 2 - Mild reactivity: Grade 3 Moderate reactivity; Grade 4- Severe reactivity (Described in detail in the Materials and methods section).
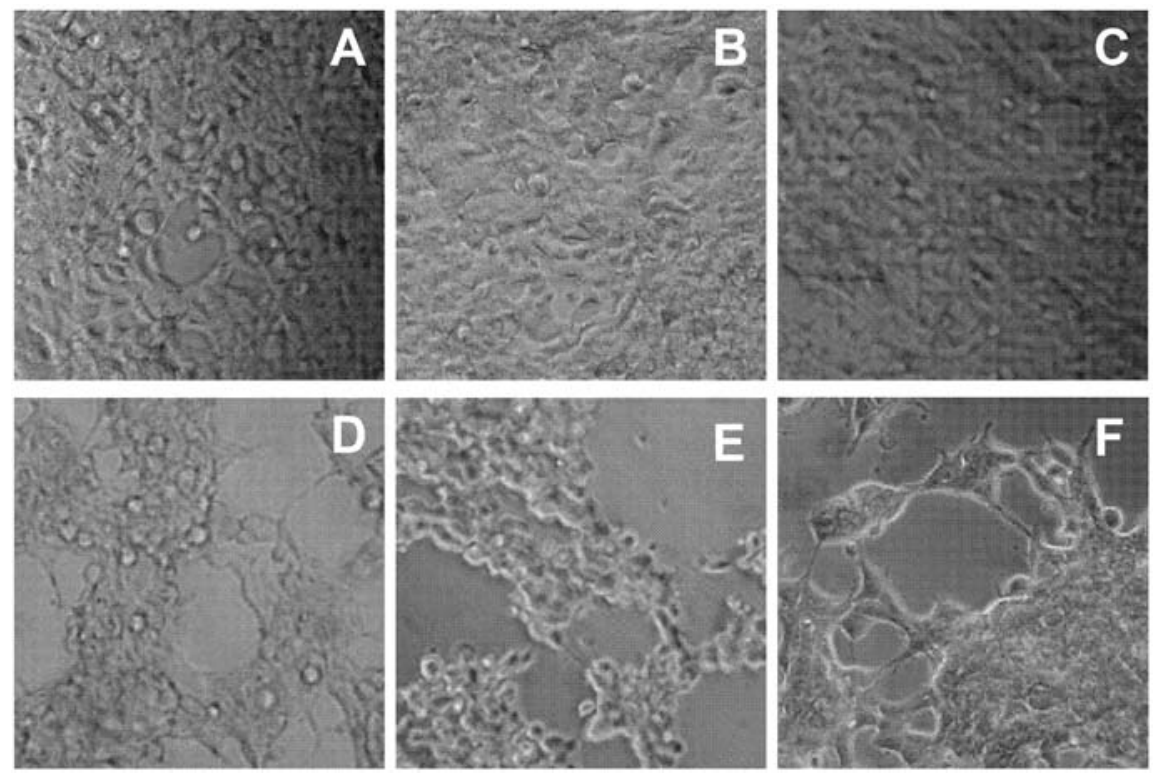

Fig. 4. Representative phase contrast microscopic imaging of HEK-293 monolayers: (A) untreated control; (B) 48 h exposure to $100 \mathrm{mg} / \mathrm{ml}$ MTA extract; (C) $48 \mathrm{~h}$ exposure to $100 \mathrm{mg} / \mathrm{ml} \mathrm{CHC}$ extract; (D) $48 \mathrm{~h}$ exposure to RF 1:100 dilution; (E) $48 \mathrm{~h}$ exposure to RF 1:25 dilution; (F) $48 \mathrm{~h}$ exposure to RF 1:25 dilution (higher magnification).

The biocompatibility of tested pulpotomy agents was further explored using a commercially available 'Cell death detection ELISA ${ }^{\text {PLUS, }}$ kit allowing simultaneous quantification of apoptotic and necrotic cell death. As shown by the results obtained (fig. 5) RF was a potent inducer of both types of cell death, in relation to concentration and treatment duration. Thus at lower levels and shorter exposure apoptosis was the dominant type of cell death in tested samples, whereas the intensified exposure in terms of both concentration and duration was consistent with a gradual increase in the proportion of necrotic cells. In a dissimilar fashion both MTA and CHC failed to induce significant increase of the DNA-fragmentation in either cytosolic fraction or supernatants, relative to control samples (data not shown), indicating that the observed decreased survival fractions in the MTT-assay could be solely attributed to antiproliferative rather to direct cytotoxic properties. 

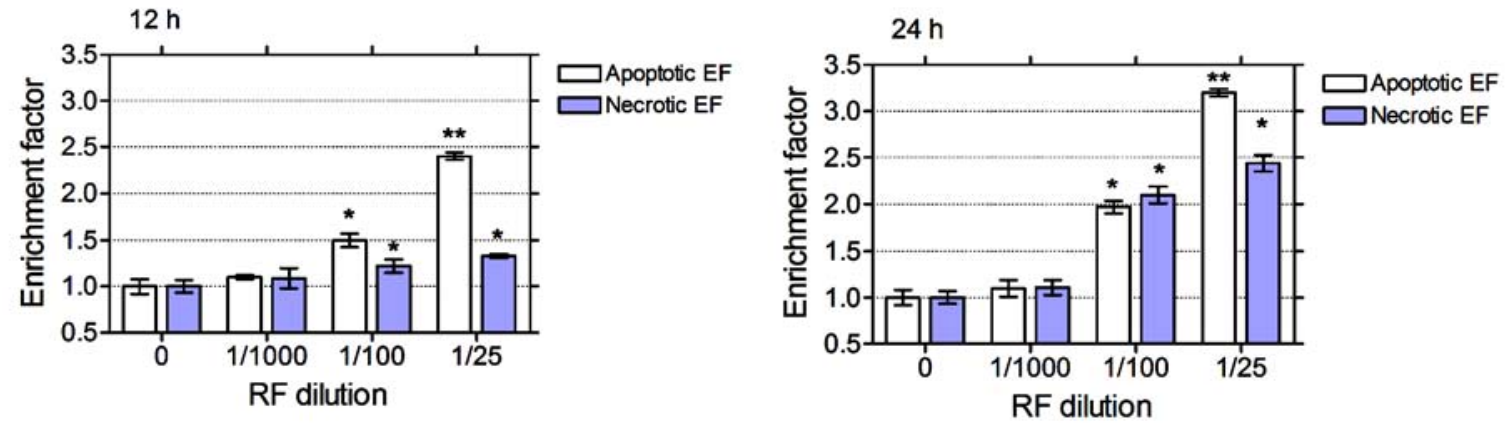

Fig. 5. Induction of apoptotic and necrotic cell death following $12 \mathrm{~h}$ or $24 \mathrm{~h}$ exposure to different dilutions of resorcinol/ formalin (RF) as assessed by 'Cell death detection ELISA ${ }^{\text {PLUS'TM }}$ kit, according to the manufacturer's instructions. Each test was run in triplicate. Asterisks indicate statistical significance vs. the untreated control $(* \mathrm{pd} \leq 0.05 ; * * \mathrm{pd} \leq 0.01)$. The results are presented as enrichment factor (EF) calculated as the $405 \mathrm{~nm}$ absorption of treated samples relative to that of untreated controls, set as 1 (Described in detail in the Materials and methods section).

\section{DISCUSSION}

The present study showed that in contrast to RF, that proved to be cytotoxic throughout a range of concentrations and exposure periods, the MTA and CHC were biocompatible, with no evidence for decreased mitochondrial dehydrogenase activity, morphological changes in monolayer integrity or induction of either apoptotic or necrotic cell death.

RF proved to be highly cytotoxic causing time- and dose-related perturbation in cellular viability of all tested cell lines. Noteworthy cytotoxicity was detected even at the 1:100 dilution which is considered clinically relevant (65). These data well correlate to the well-established toxicity of the similar mortal pulpotomy agent formocresol $(12,15-19,21$ 24) formaldehyde being the major constituent of both. The second ingredient resorcinol could at least partly contribute to the observed effects, as its intrinsic antiproliferative/ cytotoxic properties have been well documented (67-70). The relative role of the phenolic component however, is at best moderate, as it has been well documented that formaldehyde is 20 times as cytotoxic as $m$-cresol (17).

MTA and CHC had only marginal effects on mitochondrial succinate dehydrogenase, detected only at 48 h. With increased exposure the viability of tested samples was no significantly different as compared to the untreated control. This particular response can be attributed to the presence of a non-responsive pool of cell population whose proliferative activity remained unaffected allowing the cell culture to repair. These observations for reversible inhibitory effects of MTA also support those described previously by others (71-73).

An issue of special interest is the stimulatory activity of MTA regarding SaOS-2 neuroblastoma, which could be attributed to the ions released form MTA, during the extraction process providing an optimum amount of calcium for cell proliferation. These data corroborate the wellestablished osteoinductive and dentinogenic properties of MTA $(45,47,53,62,74)$.
When we assessed the proliferation/viability of human cells exposed to MTA extract solution, we found that the MTA was associated with less prominent inhibitory effects than calcium hydroxide. It is well appreciated that toxic compounds within dental materials can initiate adverse reactions in surrounding periodontal tissue. Although MTA and $\mathrm{CH}$ cement are biocompatible, they are still foreign to the tissue. The discrepancy between the extracts activity could be due to the composition of cements - MTA is composed of hydrophilic particles and contains tricalcium silicate, tricalcium aluminate, tricalcium oxide, silicate oxide, and other mineral oxides, which set in the presence of moisture (32), whereas the other cement is composed of calcium hydroxide solely (4). The latter has prominent alkaline properties and despite its very low water solubility is still capable of significant release of hydroxide ions (75). The latter could have an adverse effect on the $\mathrm{pH}$ microenvironment of cultured cells contributing to the observed effects in the MTT-bioassay. In contrast MTA is composed of insoluble silicates and oxides and is less prone to releasing ions other than calcium, the latter being obviously non-toxic within the chosen experimental conditions. These data generally corroborate the superior biosafety profile of MTA vs. calcium hydroxide $(18,76)$.

Overall, the findings from the MTT-assay corroborate preceding reports which have shown that MTA and $\mathrm{CHC}$ are biocompatible with many cell lines $(23,32,34,37-42,46$, 50). In contrast some studies have shown some albeit lowgrade cytotoxicity of MTA $(71,77)$ but this discrepancy with our results could be attributed to the experimental design and the cell lines evaluated. In a biocompatibility study, the material tested can be in either direct or indirect contact with the target cellular population. In the present study we analyzed the bioactivities of the MTA or CHC in an indirect contact with the cells for 2, 3 or 6 days. A proliferation study involving direct contact between the cultured cells and the 
freshly mixed cements would have been less meaningful, because cultured cells lack the restorative mechanisms of living tissues (78). Thus most probably the lower survival rate at various concentrations with both the MTA and CHC encountered in preceding studies is due to the employment of direct contact experimental set-up.

The morphological study conducted according to USP XXVIII further supported the significant cytotoxicity of FC and the lack of bio-reactivity of the cement-extracted eluates. These findings further evidence that the marginal inhibitory effects of CHC or MTA documented in the MTT-assay are due to slight inhibition of proliferation without direct cytotoxicity.

The in vitro cyto-compatibility testing with cell culture systems, commonly uses cell death based end-point, although they do not differentiate between the mechanistic aspects involved. Cell death is executed by two major mechanisms and correspondingly distinct signaling pathways (apoptosis and necrosis). Apoptosis is a major form of cell death, and it is an important process in a variety of different biological systems, embryonic development and in chemically induced cell death, while generally necrosis is initiated by significant suppra-physiological chemical and/or physical stimuli. Besides the mechanistic differences, at morphological level, necrosis is quite different from apoptosis, as well. During the necrotic process, the cells first swell, then the plasma membrane collapses, and subsequently, the cells are rapidly lysed, whereas in apoptosis cells are transformed into apoptotic bodies, without perturbation of the membrane integrity (79). An issue of concern regarding the relative importance of the cell death mechanisms is that while the interaction between apoptotic and phagocytic cells induces an anti-inflammatory response, necrosis appears to be critical for the initiation of inflammatory, innate- and specific immune responses $(79,80)$.

Taking into account the above considerations we performed an apoptosis/necrosis discriminating assay in HEK293 cells using an array of concentrations, higher or lower relative to that found in adjacent non-target tissue in endodontic or pulpotomy procedures tissue (equivalent to
1:100 formocresol dilution). Our observations showed simultaneous activation of necrotic and apoptotic pathways leading to cell death within the same target cellular population after 12 to $24 \mathrm{~h}$ exposure, whereby the prevalence of apoptotic and especially necrotic mechanisms was dependent on dose and exposure duration. The MTA and $\mathrm{CHC}$ extracts proved to be devoid of apoptosis- or necrosis-inductive properties which further evidences for their superior safety profile as compared to RF. These findings are in agreement with previously published data for the ability of formocresol to trigger apoptotic and necrotic cell death in cultured cells (26), and for the lack of pro-apoptotic activity of mineral trioxide aggregate $(37,51,52)$.

\section{CONCLUSIONS}

Advances in evidence-based dentistry and dental material science have gained enough evidence to support the notion that the application of formaldehyde-based products in pediatric dentistry albeit widespread is unwarranted because of safety concerns, and consequently, their use in pediatric pulp therapy is obsolete. As a result, numerous investigations for alternatives to formaldehyde/phenol devitalization medicines, some of which have shown efficacy equivalent or even superior to formocresol, have been completed. This contribution is to the best of our knowledge the first systematic, multiple end-point, in vitro evaluation of the cytotoxicity of resorcinol-formalin vs. vital pulpectomy capping agents. It gives further evidence for the biocompatibility and safety advantages of viable pulp therapy products calcium hydroxide cement and especially MTA as compared to the resorcinol/formalin preparation, routinely used in Bulgaria for decades.

There can be no doubt that from a $21^{\text {st }}$ century perspective a reparative, biologic, and patient-friendly approach to pediatric pulp therapy is preferable to the absolutist, devitalization approach of resorcinol-formalin primary tooth pulpectomy, and the replacement of the latter by clinically superior and safer alternatives is not only welcome but absolutely indispensable.

\section{Acknowledgements:}

Financial support from the Medical Science Council (MU-Sofia) through Grant № 19/2011 is gratefully acknowledged. The authors are indebted to Mrs. Theodora Atanassova, BSc for her excellent technical assistance. 


\section{REFERENCES:}

1. Milnes AR. Is formocresol obsolete? A fresh look at the evidence concerning safety issues. Pediatr Dent. 2008 MayJun;30(3):237-46. [PubMed]

2 Fuks AB, Papagiannoulis L. Pulpotomy in primary teeth: review of the literature according to standardized criteria. Eur Arch Paediatr Dent. 2006 Jun;7(2):6471; discussion 2. [PubMed]

3. Fuks AB. Current concepts in vital primary pulp therapy. Eur J Paediatr Dent. 2002 Sep;3(3):115-20. [PubMed]

4. Fuks AB. Vital pulp therapy with new materials for primary teeth: new directions and treatment perspectives. Pediatr Dent. 2008 May-Jun;30(3):211-9. [PubMed]

5. Vutov M, et al. Pediatric dentistry. Sofia: MG. 1989. (In Bulgarian)

6. Maslinkov D, et al. Guidance on practical exercises in pediatric dentistry. : MG. 1989. (In Bulgarian)

7. Gateva N, Kabaktchieva R. Anatomical characteristics of primary teeth with significance for taking inflammatory diseases of the pulpae. Diagnostics of the inflammatory diseases in primary teeth, review,Zabolekarski pregled, Sofia, 2006, vol. 88, 2:121-127 (in Bulgarian)

8. Gateva N, Kabaktchieva R. Treatment of diseases of dental pulp in primary teeth. Pulpotomy in the primary dentition.Part II, Zabolekarski pregled, Sofia, 2007, vol.89, 3, 208- 217 (in Bulgarian)

9. Ribeiro DA. Do endodontic compounds induce genetic damage? A comprehensive review. Oral Surg Oral Med Oral Pathol Oral Radiol Endod. 2008 Feb;105(2):251-6. [PubMed] [CrossRef]

10. Waterhouse PJ. "New age" pulp therapy: personal thoughts on a hot debate. Pediatr Dent. 2008 May-Jun;30(3):247-52. [PubMed]

11. Cheong C, Wong G, Law MKT, King NM. Is formocresol still safe for use in pediatric dentistry? (Part I). Dental Asia. 2008 Jul/Aug;2008:19-23.

12. Ribeiro DA, Marques ME, Salvadori DM. Antimicrobial endodontic compounds do not modulate alkylation-induced genotoxicity and oxidative stress in vitro. Oral Surg Oral Med Oral Pathol Oral Radiol Endod. 2006 Aug;102(2):e326.[PubMed] [CrossRef]

13. Block R. Are you still using formocresol? An update. J Tenn Dent Assoc. 2009 Fall;89(4):14-7. [PubMed]

14. Myers DR, Shoaf HK, Dirksen TR, Pashley DH, Whitford GM, Reynolds KE.
Distribution of ${ }^{14} \mathrm{C}$ formaldehyde after pulpotomy with formocresol. J Am Dent Assoc 1978 May;96:805-13. [PubMed]

15. Feigal RJ, Messer HH. A critical look at glutaraldehyde. Pediatr Dent. 1990 Apr-May;12(2):69-71. [PubMed]

16. Hill SD, Berry CW, Seale NS, Kaga M. Comparison of antimicrobial and cytotoxic effects of glutaraldehyde and formocresol. Oral Surg Oral Med Oral Pathol. 1991 Jan;71(1):89-95. [PubMed]

17. Jeng HW, Feigal RJ, Messer HH. Comparison of the cytotoxicity of formocresol, formaldehyde, cresol, and glutaraldehyde using human pulp fibroblast cultures. Pediatr Dent. 1987 Dec;9(4):295300. [PubMed]

18. De Menezes JV, Takamori ER, Bijella MF, Granjeiro JM. In vitro toxicity of MTA compared with other primary teeth pulpotomy agents. J Clin Pediatr Dent. 2009 Spring;33(3):217-21. [PubMed]

19. Gahyva SM, Siqueira JF Jr. Direct genotoxicity and mutagenicity of endodontic substances and materials as evaluated by two prokaryotic test systems. J Appl Oral Sci. 2005 Dec;13(4):387-92. [PubMed] [CrossRef]

20. Hagiwara M, Watanabe E, Barrett JC, Tsutsui T. Assessment of genotoxicity of 14 chemical agents used in dental practice: ability to induce chromosome aberrations in Syrian hamster embryo cells. Mutat Res. 2006 Feb 28;603(2):111-20. [PubMed] [CrossRef]

21. Ozaki T. Cytotoxicity of formocresol on cultured mammalian cells. Shigaku. 1988 Feb;75(6):1027-38. [PubMed]

22. Ribeiro DA, Scolastici C, De Lima PL, Marques ME, Salvadori DM. Genotoxicity of antimicrobial endodontic compounds by single cell gel (comet) assay in Chinese hamster ovary (CHO) cells. Oral Surg Oral Med Oral Pathol Oral Radiol Endod. 2005 May;99(5):637-40. [PubMed] \{CrossRef]

23. Wang XL, Song M, Lou JN, Niu XY. The study of cytotoxicity of different intracanal medications and cell rehabilitation on human periodontal ligament fibroblasts. Shanghai Kou Qiang Yi Xue. 2007 Oct;16(5):512-9. [PubMed]

24. Holan G, Eidelman E, Fuks AB. Long-term evaluation of pulpotomy in primary molars using mineral trioxide aggregate or formocresol. Pediatr Dent. 2005 Mar-Apr;27(2):129-36. [PubMed]

25. Huang TH, Yang CC, Ding SJ, Yeng
M, Kao CT, Chou MY. Inflammatory cytokines reaction elicited by root-end filling materials. $J$ Biomed Mater Res $B$ Appl Biomater. 2005 Apr;73(1):123-8. [PubMed] [CrossRef]

26. Cardoso ML, Todaro JS, Aguirre MV, Juaristi JA, Brandan NC. Morphological and biochemical changes during formocresol induced cell death in murine peritoneal macrophages: apoptotic and necrotic features. Cell Biol Toxicol. 2010 Oct;26(5):445-55. [PubMed] [CrossRef]

27. Rolling I, Thylstrup A. A 3-year follow-up study of pulpotomized primary molars treated with the formocresol technique. Scand J Dent Res. 1975 Mar;83(2):47-53. [PubMed]

28. Ferreira DC, Brito DG, Cavalcanti BN. Cytokine production from human primary teeth pulp fibroblasts stimulated by different pulpotomy agents. J Dent Child (Chic). 2009 Sep-Dec;76(3):194-8. [PubMed]

29. Zarzar PA, Rosenblatt A, Takahashi CS, Takeuchi PL, Costa-Junior LA. Formocresol mutagenicity following primary tooth pulp therapy: an in-vivo study. J Dent. 2003;31:479-85. [PubMed] [CrossRef]

30. Swettman SC, Martindale ED: The Complete Drug Reference, 36th Ed. London: Pharmaceutical Press. 2009.

31. Haney KL. Current trends in primary tooth pulp therapy. $J$ Okla Dent Assoc. 2007 Oct;99(2):28-37; quiz 8. [PubMed]

32. Ng FK, Messer LB. Mineral trioxide aggregate as a pulpotomy medicament: a narrative review. Eur Arch Paediatr Dent. 2008 Mar;9(1):4-11. [PubMed]

33. Naik S, Hegde AH. Mineral trioxide aggregate as a pulpotomy agent in primary molars: an in vivo study. J Indian Soc Pedod Prev Dent. 2005 Mar;23(1):13-6. [PubMed] [CrossRef]

34. Gohring KS, Lehnert B, Zehnder M. [Indications for use of MTA, a review. Part 1: Chemical, physical and biological properties of MTA]. [Article in French, German] Schweiz Monatsschr Zahnmed. 2004;114(2):143-53. [PubMed]

35 . Innes $\mathrm{N}$. Better outcomes in pulpotomies on primary molars with MTA. Evid Based Dent. 2007;8(1):11-2. [PubMed] [CrossRef]

36. Kabaktchieva R, Gateva N. Vital pulpotomy in primary teeth with mineral 
trioxide aggregate (MTA). J of IMAB. 2009;15(2):102-108. [CrossRef]

37. Huang TH, Ding SJ, Hsu TC, Kao CT. Effects of mineral trioxide aggregate (MTA) extracts on mitogen-activated protein kinase activity in human osteosarcoma cell line (U2OS). Biomaterials. 2003 Oct;24(22):3909-13. [PubMed] [CrossRef]

38. Karimjee CK, Koka S, Rallis DM, Gound TG. Cellular toxicity of mineral trioxide aggregate mixed with an alternative delivery vehicle. Oral Surg Oral Med Oral Pathol Oral Radiol Endod. 2006 Oct;102(4):e115-20. [PubMed] [CrossRef]

39. Ribeiro DA, Duarte MA, Matsumoto MA, Marques ME, Salvadori DM. Biocompatibility in vitro tests of mineral trioxide aggregate and regular and white Portland cements. J Endod. 2005 Aug;31(8):605-7. [PubMed]

40. Ribeiro DA, Matsumoto MA, Duarte MA, Marques ME, Salvadori DM. Ex vivo biocompatibility tests of regular and white forms of mineral trioxide aggregate. Int Endod J. 2006 Jan;39(1):26-30. [PubMed] [CrossRef]

41. Ribeiro DA, Matsumoto MA, Duarte MA, Marques ME, Salvadori DM. In vitro biocompatibility tests of two commercial types of mineral trioxide aggregate. Braz Oral Res. 2005 Jul-Sep;19(3):183-7. [PubMed] [CrossRef]

42. Ribeiro DA, Sugui MM, Matsumoto MA, Duarte MA, Marques ME, Salvadori DM. Genotoxicity and cytotoxicity of mineral trioxide aggregate and regular and white Portland cements on Chinese hamster ovary (CHO) cells in vitro. Oral Surg Oral Med Oral Pathol Oral Radiol Endod. 2006 Feb;101(2):258-61. [PubMed] [CrossRef]

43. Tani-Ishii N, Hamada N, Watanabe $\mathrm{K}$, Tujimoto $\mathrm{Y}$, Teranaka $\mathrm{T}$, Umemoto $\mathrm{T}$. Expression of bone extracellular matrix proteins on osteoblast cells in the presence of mineral trioxide. J Endod. 2007 Jul;33(7):836-9. [PubMed] [CrossRef]

44. Vajrabhaya LO, Korsuwannawong S, Jantarat J, Korre S. Biocompatibility of furcal perforation repair material using cell culture technique: Ketac Molar versus ProRoot MTA. Oral Surg Oral Med Oral Pathol Oral Radiol Endod. 2006 Dec;102(6):e48-50. [PubMed] [CrossRef]

45. Moretti AB, Sakai VT, Oliveira TM, Fornetti AP, Santos CF, Machado MA, et al. The effectiveness of mineral trioxide aggregate, calcium hydroxide and formocresol for pulpotomies in primary teeth. Int Endod J. 2008 Jul;41(7):547-55. [PubMed] [CrossRef]
46. Osorio RM, Hefti A, Vertucci FJ, Shawley AL. Cytotoxicity of endodontic materials. J Endod. 1998 Feb;24(2):91-6. [PubMed] [CrossRef]

47. Salako N, Joseph B, Ritwik P, Salonen J, John P, Junaid TA. Comparison of bioactive glass, mineral trioxide aggregate, ferric sulfate, and formocresol as pulpotomy agents in rat molar. Dent Traumatol. 2003 Dec;19(6):314-20. [PubMed] [CrossRef]

48. Souza NJ, Justo GZ, Oliveira CR, Haun M, Bincoletto C. Cytotoxicity of materials used in perforation repair tested using the V79 fibroblast cell line and the granulocyte-macrophage progenitor cells. Int Endod J. 2006 Jan;39(1):40-7. [PubMed] [CrossRef]

49. Torabinejad M, Hong CU, Pitt Ford TR, Kettering JD. Cytotoxicity of four root end filling materials. J Endod. 1995 Oct;21(10):489-92. [PubMed]

50. De-Deus G, Canabarro A, Alves G, Linhares A, Senne MI, Granjeiro JM. Optimal cytocompatibility of a bioceramic nanoparticulate cement in primary human mesenchymal cells. J Endod. 2009 Oct;35(10):1387-90. [PubMed] [CrossRef]

51. Gorduysus M, Avcu N, Gorduysus O, Pekel A, Baran Y, Avcu F, et al. Cytotoxic effects of four different endodontic materials in human periodontal ligament fibroblasts. $J$ Endod. 2007 Dec;33(12):1450-4. [PubMed] [CrossRef]

52. Hernandez EP, Botero TM, Mantellini MG, McDonald NJ, Nor JE. Effect of ProRoot MTA mixed with chlorhexidine on apoptosis and cell cycle of fibroblasts and macrophages in vitro. Int Endod J. 2005 Feb;38(2):137-43. [PubMed] [CrossRef]

53. Agamy HA, Bakry NS, Mounir MM, Avery DR. Comparison of mineral trioxide aggregate and formocresol as pulp-capping agents in pulpotomized primary teeth. Pediatr Dent. 2004 Jul-Aug;26(4):302-9. [PubMed]

54. Caicedo R, Abbott PV, Alongi DJ, Alarcon MY. Clinical, radiographic and histological analysis of the effects of mineral trioxide aggregate used in direct pulp capping and pulpotomies of primary teeth. Aust Dent J. 2006 Dec;51(4):297-305. [PubMed] [CrossRef]

55. Ng FK, Messer LB. Mineral trioxide aggregate as a pulpotomy medicament: an evidence-based assessment. Eur Arch Paediatr Dent. 2008 Jun;9(2):58-73. [PubMed]

56. Noorollahian H. Comparison of mineral trioxide aggregate and formocresol as pulp medicaments for pulpotomies in primary molars. Br Dent J. 2008 Jun 14;204(11):E20. [PubMed] [CrossRef]

57. Saltzman B, Sigal M, Clokie C, Rukavina J, Titley K, Kulkarni GV. Assessment of a novel alternative to conventional formocresol-zinc oxide eugenol pulpotomy for the treatment of pulpally involved human primary teeth: diode laser-mineral trioxide aggregate pulpotomy. Int J Paediatr Dent. 2005 Nov;15(6):437-47. [PubMed] [CrossRef]

58. Sonmez D, Sari S, Cetinbas T. A Comparison of four pulpotomy techniques in primary molars: a long-term follow-up. $J$ Endod. 2008 Aug;34(8):950-5. [PubMed] [CrossRef]

59. Aeinehchi M, Dadvand S, Fayazi S, Bayat-Movahed S. Randomized controlled trial of mineral trioxide aggregate and formocresol for pulpotomy in primary molar teeth. Int Endod J. 2007 Apr;40(4):261-7. [PubMed] [CrossRef]

60. Eidelman E, Holan G, Fuks AB. Mineral trioxide aggregate vs. formocresol in pulpotomized primary molars: a preliminary report. Pediatr Dent. 2001 JanFeb;23(1):15-8. [PubMed]

61. Farsi N, Alamoudi N, Balto K, Mushayt A. Success of mineral trioxide aggregate in pulpotomized primary molars. J Clin Pediatr Dent. 2005 Summer;29(4):307-11. [PubMed]

62. Maroto M, Barberia E, Planells P, Garcia Godoy F. Dentin bridge formation after mineral trioxide aggregate (MTA) pulpotomies in primary teeth. Am J Dent. 2005 Jun;18(3):151-4. [PubMed]

63. Peng L, Ye L, Tan H, Zhou X. Evaluation of the formocresol versus mineral trioxide aggregate primary molar pulpotomy: a meta-analysis. Oral Surg Oral Med Oral Pathol Oral Radiol Endod. 2006 Dec;102(6):e40-4. [PubMed]

64. Subramaniam P, Konde S, Mathew S, Sugnani S. Mineral trioxide aggregate as pulp capping agent for primary teeth pulpotomy: 2 year follow up study. $J$ Clin Pediatr Dent. 2009 Summer;33(4):311-4. [PubMed]

65. Segura JJ, Jimenez-Rubio A, Calvo JR. Effects of formocresol alone vs. formocresol with eugenol on macrophage adhesion to plastic surfaces. Pediatr Dent. 1998 May-Jun;20(3):177-80. [PubMed]

66. Konstantinov SM, Eibl H, Berger MR. BCR-ABL influences the antileukaemic efficacy of alkylphosphocholines. Br J Haematol. 1999 
Nov;107(2):365-80. [PubMed] [CrossRef] 67. Newby CS, Barr RM, Greaves MW, Mallet AI. Cytokine release and cytotoxicity in human keratinocytes and fibroblasts induced by phenols and sodium dodecyl sulfate. $J$ Invest Dermatol. 2000 Aug;115(2):292-8. [PubMed] [CrossRef]

68. Passi S, Picardo M, Nazzaro-Porro M. Comparative cytotoxicity of phenols in vitro. Biochem J. 1987 Jul 15;245(2):53742. [PubMed]

69. Skowron J, Zapor L. Cytotoxicity of resorcinol under short- and long-term exposure in vitro. Int J Occup Saf Ergon. 2004;10(2):147-56. [PubMed]

70. Zapor L. Toxicity of some phenolic derivatives-in vitro studies. Int J Occup Saf Ergon. 2004;10(4):319-31. [PubMed]

71. De Deus G, Ximenes R, GurgelFilho ED, Plotkowski MC, Coutinho-Filho T. Cytotoxicity of MTA and Portland cement on human ECV 304 endothelial cells. Int Endod J. 2005 Sep;38(9):604-9. [PubMed] [CrossRef]
72. Estrela C, Bammann LL, Estrela CR, Silva RS, Pecora JD. Antimicrobial and chemical study of MTA, portland cement, calcium hydroxide paste, Sealapex and Dycal. Braz Dental J 2000;11:3-9. [PubMed]

73. Saidon J, He J, Zhu Q, Safavi K, Spangberg LS. Cell and tissue reactions to mineral trioxide aggregate and Portland Cement. Oral Surg Oral Med Oral Pathol Radiol Endodont. 2003;95:483-9. [PubMed] [CrossRef]

74. Laurent P, Camps J, De Meo M, Dejou J, About I. Induction of specific cell responses to a $\mathrm{Ca}(3) \mathrm{SiO}(5)$-based posterior restorative material. Dent Mater. 2008 Nov;24(11):1486-94. [PubMed] [CrossRef]

75. Rowe RC, Sheskey PJ, Quinn ME, eds. Handbook of Pharmaceutical Excipients 6th Edition. London. Chicago: Pharmaceutical Press 2009; p. 185.

76. Camargo SE, Camargo $\mathrm{CH}$, Hiller KA, Rode SM, Schweikl H, Schmalz G. Cytotoxicity and genotoxicity of pulp capping materials in two cell lines. Int Endod J. 2009 Mar;42(3):227-37. [PubMed] [CrossRef]

77. Miranda RB, Fidel SR, Boller MA. L929 cell response to root perforation repair cements: an in vitro cytotoxicity assay. Braz Dent J. 2009;20(1):22-6. [PubMed] [CrossRef]

78. Ding SJ, Kao CT, Chen CL, Shie MY, Huang TH. Evaluation of human osteosarcoma cell line genotoxicity effects of mineral trixoide aggregate and calcium silicate cements. $J$ Endod. 2010 Jul;36(7):1158-62. [PubMed] [CrossRef]

79. Majno G, Joris I. Apoptosis, oncosis, and necrosis. An overview of cell death. . Am J Pathol 1995. 1995 Jan;146(1):3-15. [PubMed]

80. Marsden VS, Strassen A. Control of apoptosis in the immune system: Bcl-2, BH3-only proteins and more. Ann Rev Immunol. 2003; 21:71-105. [PubMed] [CrossRef]

\section{Address for correspondence:}

Rossitza Kabaktchieva, Associate professor, PhD, $M D$

Department of Pediatric Dental Medicine, Faculty of Dental Medicine, Sofia 1, St. George Sofiiyski Str., 1000 Sofia, Bulgaria mob.: +359/888 099453 E-mail: r_kabaktchieva@mail.bg 